\title{
Teacher's Job Satisfaction And Its Relationship With Organizational Commitment In Ethiopian Primary Schools: Focus On Primary Schools Of Bonga Town
}

\author{
Teferi Getahun \\ Bekalu Ferede Tefera \\ Abebe Hunde Burichew
}

Department of Educational Planning and Management, College of Education and Behavioral sciences, Jimma University

doi: 10.19044/esj.2016.v12n13p380 URL:http://dx.doi.org/10.19044/esj.2016.v12n13p380

\begin{abstract}
This study explored the extent of organizational commitment and how this may support or hinder a range of job satisfaction of teachers examined in the Ethiopian primary schools.The research employed correlation design. To this end, one hundred and eighteen 118 (58.1\%) teachers were selected from six primary schools using simple random sampling technique and participated in the study. The researchers collected the relevant data from teachers using Spector's (1997) adopted version of job satisfaction survey (JSS) and Meyer and Allen's (1990) organizational commitment questionnaire (OCQ). The researchers analyzed the data using mean, standard deviation, correlation analysis and t-test. The result showed that there was evidence of positive correlation between teachers' job satisfaction and their organizational commitment in the sampled schools. Regardless of this, the findings of the study revealed that gender was the only demographic variable that had significant positive relationship with job satisfaction. The other demographic variables such as age, gender, marital status and level of education did not show significant relationship with teachers' job satisfaction in the sampled schools. Consequent up on this finding it was concluded that schools can enhance the level of teachers' organizational commitment by creating a more satisfying working environment. As to the demographic variable, since some of the finding contradicts with the existing literature, we need to undertake more studies to have better understanding of the nature of the relationship between teachers demographic variables, job satisfaction and organizational commitment in developing countries context.
\end{abstract}


Keywords: Job satisfaction, Organizational commitment, Primary school, Ethiopia.

\section{Back ground of the study}

Teacher is the central element in educational system holding various important responsibilities. The overall performance of schools depends upon their teachers and ultimately their level of commitment and job satisfaction. Understanding their behaviors and attitudes in organizations therefore, needs more attention (Tsui \& Cheng, 1999). The study of behaviors within organizational setting has highlighted critical variables that are supportive or detrimental to the performance of workforce. This notion holds true while focusing on quality of human resources that is major factor which contribute significantly to the organizational success (Pohlman \& Gardiner, 2000).

Job satisfaction is crucial problem for all organization no matter whether in public or private organizations or working in advanced or underdeveloped countries. One of the purposes for this degree of interest is that satisfied personnel is reported as committed workers and commitment is indication for organizational output and effectual operations (Robbins \& Coulter, 2005, p. 370).

In today's understanding of administration, the effective use of the human factor as a base for the organization is regarded as an important indicator of success or failure. Therefore, employees' levels of job satisfaction and organizational commitment have become subject to research (Taşdan \& Tiryaki, 2008).

Job satisfaction affects the health of staff, their efficiencies, labor relationships in the organization and the organization's overall efficiency. With regard to these aspects, job satisfaction has individual, organizational and social outcomes. According to (Brown \& Sargeant 2007), these outcomes may be sometimes positive or negative. For example, they may represent more negatively through reflecting low efficiency, work stoppage, absenteeism, tardiness or theft. On the contrary they may represent more positively via high efficiency, loyalty, punctuality, self devotion and commitment.

Job satisfaction amongst teachers is a multifaceted construct which is imperative for the retention of these teachers and is a significant determinant of teacher commitment as well as a contributor to school effectiveness. Research, however, has revealed a wide range of differences contributing to job satisfaction amongst teachers (Shann, 2001). In the process of development of any educational system around the world, job satisfaction is vital. Special training, a high level of education, focus competencies, educational resources, and strategies determine whether or how educational success and performance happen (Ololube, N.P. 2006). 
Job satisfaction of teachers has been a focus of attention for educational researchers; this is because of the prevailing links between job satisfaction and organizational behavior that might be explained in terms of commitment, absenteeism, turnover, efficiency and productivity (Reference). High attrition rates amongst teachers could be attributed to job dissatisfaction (Wisniewski \& Gargiulo 1997). They concluded that lack of recognition, few opportunities for promotion, excessive paperwork, loss of autonomy, lack of supplies, low pay, and stressful interpersonal interactions all contributed to teachers' decisions to leave schools.

International research literature shows that the extent to which teachers are satisfied with their jobs and working conditions is likely to have significant consequences for the retention of teachers within the profession, for their approach to teaching, for the creation of collegial relations within a school, and for student outcomes (Crossman \& Harris, 2006; Chaplain, 1995).

Teachers are arguably the most important professional in nation's development (Bishay, 1996) consequently; their satisfaction at work is paramount to educational development of the nation. Research into teacher job satisfaction is thus significant in order to retain teachers in the educational profession and to encourage increased teacher productivity.

Similar to job satisfaction, “organizational commitment” has recently become a field of study in management which has attracted interest. (Meyer and Herscovitch 2001, p. 301) propose that commitment is "a force that binds an individual to a course of action of relevance to one or more targets" in other words.' (Mowday, Steers and Porter 1982), defined Organizational commitment is the strength of an individual's identification and involvement in a particular organization as characterized by a strong belief in and acceptance of the organization's goals and values (value commitment) along with a readiness to exert considerable effort on behalf of the organization and to remain a member (commitment to stay ).

Organizational commitment is regarded as an important feature of educational institutions (Brown and Sargeant, 2007). From the perspective of teachers, organizational commitment is the commitment to the school. This commitment includes a psychological contract which consists of open and latent pledges between teachers and the school. This contract shows the level of physiological relationship between teachers and the school. As a societal value, commitment reduces opportunism.

There are several factors affecting organizational commitment, however, it is possible to classify these as individual, organizational and nonorganizational (environmental) factors. Individual factors often include job expectations, physiological contracts and personal characteristics (gender, marital status, seniority, position, education, race, and social culture). 
Teacher commitment is recognized by Srisrankulwong (2005) as an intrinsic quality of a good teacher. It reflects job satisfaction, morale, motivation, identity and professional meaning. Committed teachers will work devotedly for the values and school goals, as well as, engage in promoting the development and wellbeing of the students teachers are committed to both the organization and the profession in successful schools (Park, Henkin,\& Egley, 2005).

According to Day (2000), teacher commitment is multidimensional. $\mathrm{He} / \mathrm{she}$ can feel commitment to the organization, to the students, for his/her career continuance, for the professional knowledge base and/or towards the teaching profession. Commitment to the teaching becomes a reason of internal driving force for a good performance and commitment to the institution becomes stronger motivational force for admirable work.

The level of employees' organizational commitment will possibly ensure that they are better suited to receiving both extrinsic rewards (which include remuneration and benefits) and psychological rewards (which include job satisfaction and associations with fellow employees) related to associations. Organizational commitment is generally assumed to reduce abandonment behaviors, which include tardiness and turnover. A fully committed employees' lead to organizational success and thriving in today's' dynamic organizational context (Yocel, 2012)

The literature suggests that individuals become committed to organizations for a variety of reasons, including an affective attachment to the values of the organization, a realization of the costs involved with leaving the organization, and a sense of obligation to the organization (Meyer \& Allen, 1997). Research recommends that organizational commitment also leads to lower degrees of both absence and turnover and actually, it is a good sign of turnover then job satisfaction (Robbins \& Coulter, 2005:375). The organizational commitment is partially the effect of intrinsic personal characteristics and partially the consequence of how peoples understand the institution and their instant job function (Daneshfard \& Ekvaniyan, 2012)

The three-component model of commitment developed by (Meyer \& Allen 1997) arguably dominates organizational commitment research (Meyer et al., 2002).they discuss organizational commitment as emotional, continuity and normative responses.

Affective commitment refers to an employee's emotional attachment to, identification with, and involvement in a particular organization. Workers stay with an establishment because he needs to. The employee develops with the organization primarily via positive work experiences. Continuance commitment refers to commitment based on the costs that the employee associates with leaving the organization. Normative commitment refers to 
the employee's feelings of obligation to stay with the organization (Lawrence \& Lawrence, 2009).

Several past studies indicate that there is a positive relationship between job satisfaction and organizational commitment (Ayeni and Phopoola, 2007; Clugston, 2000; Morrison, 1997; Mathieu \& Zajac, 1990). Employees tend to be committed to an organization, and employees who are satisfied and committed are more likely to attend work, stay with an organization, arrive at work on time, perform well and engage in behaviors helpful to the organization (Aamodt 2007). Furthermore, Delaney (2002) asserts that job satisfaction can be proven to lead to organizational commitment, as the employer is likely to hire the one with a higher level of commitment to the job.

In general, if education is a priority for national development, then maintaining the quality of the education must be the priority of government; and attempts to improve quality of education will never succeed if teachers' job satisfaction and commitment is ignored. Thus, the study of relationship between these variables i.e. job satisfaction and commitment unarguable becomes a topic of prime importance and great interest for study and further research among public primary school teachers of Ethiopia.

\section{Statement of the Problem}

In many educational contexts, teachers increasingly leave the profession after a few years in service. In addition studies worldwide have found that teachers are exposed to the highest level of job related stress and that they are less satisfied with their jobs than any other professional group. Research into teacher satisfaction has a great effect and value because job dissatisfaction causes little commitment and productivity, reduced ability to meet student needs, certain degrees of psychological disorders and high levels of stress related disability (Karavas, 2010). There is evidence indicating that most teachers in most school systems are not satisfied with their jobs, moreover, there is high turnover condition among the teachers. This may be a result of low pay, promotion, supervision, nature of work, fringe benefit etc.(Dinham \& Scott, 1998) study of teachers who resigned from the teaching profession indicated teachers' dissatisfaction centers on school systems and relate to school structure or administration policies.

The issue of teacher's job satisfaction and commitment has been one of pressing educational issues in Ethiopia. Even though, teachers organizational commitment is missing from previous studies, few studies have tried to investigate teachers job satisfaction and associated factors in Ethiopia. The inequality in salary between teachers and non-teachers with similar qualifications, and the negative relationship between inadequate salary or career structure and job satisfaction has been confirmed by 
empirical data. Locally, Akiliu (1967) and Ayalew (1991) have also identified low or inequitable salary and inadequate chances for career advancement as critical matters in teacher job dissatisfaction. More recently Getachew (1999) and Manna and Tesfay (2000) have reached similar conclusions that teachers job satisfaction and commitment are low in Ethiopia.

Job satisfaction studies in Ethiopia have been carried out in recent years, Fenot (2005) and Gedefaws's (2012) conducted such studies in Addis Ababa .Their study showed that teachers' job satisfaction is most closely related to those aspects that are intrinsic to the task of teaching namely, teacher efficacy and development. Especially, Gedefaws's (2012) study included 300 secondary school teachers and 10 interview participants in Addis Abeba. The results indicated that the teachers were significantly dissatisfied with their work. Salary and benefits emerged as the primary dissatisfying aspects of all the work factors. Other causes of low level of satisfaction were related to poor fringe benefits and opportunists for promotion, the management style of the principals, the lack of decisionmaking opportunities for teachers, lack of opportunity to develop personality, and the poor relationships teachers had with principals and parents.

Fenot (2005, p. 78) noted that nearly two-thirds of teachers (64.7\%) have tentative or definite plans to leave the profession. Fifty percent of these indicated that they will continue teaching until they get another job and $14.2 \%$ stated they definitely plan to leave teaching. Less than $23.3 \%$ intend to remain in the profession until retirement, out of 278 primary teachers in Addis Ababa, Ethiopia. Why do teachers leave their jobs? Finding the factors that influence attrition is complicated because the phenomenon has multiple aspects in economic, social, political personal, and school arenas.

Owing to these, the country's education sector is known to have the highest movement of teachers between schools and in their actual leaving of the profession. The attrition rate of teachers especially in public schools and in remote areas is also very critical.

The need for the research also emanates from empirical evidence in that the researchers have been witnessing many of the above challenges in their more than 17 years of service in the education sector of Ethiopia. There is movement of teachers from school to other schools. At the same time some teachers abandoning the teaching profession and joined other professions. Teachers, among other workers failed to earn a living wage to provide for their basic needs. Literature revealed that lack of job satisfaction, resulted in frequent teacher absenteeism from school, aggressive behavior towards colleagues and learners and early exits from the teaching profession. With regard to this problem, this study was designed to examine the 
relationship between teacher's job satisfaction and organizational commitment among primary school of Ethiopia with special focus on Bonga town.

\section{The Rresearch Questions}

1. What are the levels of organizational commitment and teachers' perceived job satisfaction in the Ethiopian primary schools?

2. Is there a significant relationship between teacher's job satisfaction and organizational commitment?

3. Which demographic variables (gender, marital status, and educational level) are associated with teachers' perceived job satisfaction and organizational commitment?

\section{Purpose of the study}

The purpose of the study was to examine the prevailing relationships between teachers' job satisfaction and organizational commitment in the context of Ethiopian Primary schools.

\section{Research Design and Method Research Design}

This study aims at analyzing the relationship between teachers' job satisfaction and organizational commitment. To this end, the researchers primarily used a correlation research design.

\section{Sampling}

In the studied area, there were six primary schools and all of them were included in the study. Within these six schools, there were a total of 203 teachers (Females 94 and Males 109). The researchers used a proportional stratified sampling technique to select samples of teachers participants, $(n=118)$. This sample accounts for $58 \%$ of the total population.

\section{Instrument}

For this study, the researchers used a standardized questionnaire to collect data from teachers' participants. The questionnaire consists of three parts. The first part of the questionnaire is devoted to demographic variables of the respondents. The second part consists of a set of items that measure teacher's level of job satisfaction. These items were generated from Spector's (1997) job satisfaction survey (JSS). The third part of the questionnaire measures teachers' organizational commitment which is divided into 3 sections. The first section (a) seeks to measure items on teachers Affective commitment, the second sections (b) seeks to measure items on Continuance commitment, the third section (c) seeks to measure 
items on Normative commitment of the respondents. Items for measuring teachers' commitment were adopted from organizational commitment questionnaire (OCQ) (Meyer \& Allen, 1990). A five point Likert-type scale items ranging from $1=$ Strongly Disagree, to 5=Strongly Agree was used for rating both teachers level of job satisfaction and commitments.

In order to ensure content validity of the instrument, the items in the questionnaire were critically examined by the researchers and participants of the pilot study. Furthermore, in order to ensure its reliability, the researchers conducted a pilot study prior to the main data collection. The pilot study results were computed based on 30 returned questionnaires. The preliminary analysis of the pilot data showed that the Cronbach's alpha coefficients for both teacher's job satisfaction and organizational commitment scales for all the items were 0.93 which shows that the questionnaires are reliable. A total of 132 questionnaires were distributed out of which 118 (89.39\%) were properly filled and returned.

\section{Data Analysis techniques}

The researchers analyzed the quantitative data collected from the respondents using SPSS version 20 and used various statistical analysis techniques. The overall levels of teachers' job satisfaction and commitment were analyzed using descriptive statistic such as frequency, mean and standard deviations. Correlation analysis (Pearson Correlation Coefficient) was used to determine the relationship between teachers' demographic variables, job satisfaction and organizational commitment. Finally t-test was employed to examine whether or not there is statistically significant difference between male and female, married and unmarried teachers in their job satisfaction and organizational commitment.

\section{Ethical Issues}

The researchers addressed important ethical issues during the research process. In this regard, permission to carry out the study in the selected organization was sought from Bonga town educational office and school principals. Furthermore, the researcher explained the objectives and significance of the study to the respondent and that all information will be kept confidential.

\section{Results}

\section{Demographic Information}

Description of demographic characteristics of the respondents has provided some basic information about the samples teacher participants in terms of sex, age, marital status, educational status and teaching experience. 
Table 2 presents the summary of the demographic characteristics of the respondents.

Table 1: Demographic Characteristics of Respondents

\begin{tabular}{lclll}
\hline Demographic variables & & & F & Percentage \\
\hline Sex & F & 67 & 56.80 \\
& M & 51 & 43.20 \\
Age & Total & 118 & 100 \\
& $23-30$ & 22 & 18.64 \\
& $31-40$ & 45 & 38.14 \\
& $41-50$ & 32 & 27.12 \\
Marital Status & $51-60$ & 19 & 16.10 \\
& Total & 118 & 100 \\
Educational & Single & 110 & 93.20 \\
Status & Married & 8 & 6.80 \\
Teaching & Total & 118 & 100 \\
Experience & Diploma & 16 & 13.60 \\
& Degree & 102 & 86.40 \\
& Total & 118 & 100 \\
& $2-10$ & 16 & 13.56 \\
& $11-20$ & 48 & 40.68 \\
& $21-30$ & 37 & 31.36 \\
& $31-40$ & 17 & 14.40 \\
& Total & 118 & 100 \\
& & & \\
\hline
\end{tabular}

As shown in Table 1, 67 (56.8\%) and 51(43.2 \%) teachers respondents were female and males, respectively. Also, the same table shows that majority $45(38.14 \%)$ of the respondents were in the age range of 31-40 years whereas only $19(16.1 \%)$ were in the age range of 51-60 years. In addition, Table 1 , depicts that $110(93.2 \%)$ and 8 (6.8\%) respondent teachers were married and single, respectively. As far as the level of education is concerned, great majority of the respondents 102(86.4\%) were Bachelor Degree holders. Furthermore, the same table showed that $48(40.6 \%)$ had teaching experience of 11-20 years while only 16(13.56\%) of the respondent teachers had a teaching experience of between 2-10 years. Given the context of Ethiopian primary schools that favors male teachers, this finding indicates that it was attempted to balance the proportion of male and female teachers in the sample. In addition, as indicated in table 1, majority of the respondents have long year of experience, married and relatively older. This is due to the reason that length of experience is a major criterion to teach in urban schools in Ethiopia.

\section{Levels of Teachers Job Satisfaction and Organizational Commitment}

The descriptive statistics namely, mean and standard deviations were used to analyze teachers' level of job satisfaction and commitment. Table 2 
shows the level of teachers job satisfaction and commitment in the sampled schools.

Table 2: Teachers Level of Job Satisfaction and Organizational Commitment $(\mathrm{n}=$ 118)

\begin{tabular}{lll}
\hline & Mean & $S D$ \\
\hline Job satisfaction & 2.72 & 0.47 \\
Organizational commitment & 3.43 & 0.71 \\
\hline
\end{tabular}

As shown in table 2, teachers in the sampled schools had slightly below average $(M e a n=, 2.72, S D=0.47)$ level of job satisfaction. Similarly, the teachers level of organizational commitment in the sampled school was found to be high (Mean=3.43, $S D=0.71)$.

\section{Level of models of organizational commitment}

Teachers' level of commitment is further disaggregated to the three types of commitment, namely affective commitment, continual commitment and normative commitment. Table 3 , shows disaggregate mean and standard deviation of the three types of commitment.

Table 3: Mean Scores of the Respondents on the Components of Organizational

Commitment $(\mathbf{n}=118)$

\begin{tabular}{ccc}
\hline & Mean & SD \\
\hline Affective commitment & 3.51 & 0.86 \\
Continuance Commitment & 3.31 & 0.82 \\
Normative Commitment & 3.40 & 0.85 \\
\hline
\end{tabular}

Table 3, depicted that teachers level Affective Commitment in the sampled school was relatively high (Mean=3.51, SD0.86) whereas their level of Normative commitment was the relatively the lowest (Mean=3.40, $\mathrm{SD}=0.85$ ). This means that teachers in the sampled school have high emotional attachment to their school and relatively lower feeling level of obligation to stay in their present schools.

The Relationship between Teachers Job Satisfaction, Organizational Commitment and Demographic Variables (Age and Teaching Experience)

In order to measure the relationship between teachers' job satisfaction, overall organizational commitment and demographic variables, Pearson's Correlation Coefficients was determined. Table 4 shows the intercorrelation matrix between the variables. 
Table 4: An Inter-correlation Matrix between Teachers job Satisfaction, Organizational Commitment and some demographic variables $(\mathrm{N}=118)$

\begin{tabular}{lllllll}
\hline & EXP & TJS & AC & CC & NC & OC \\
\hline AGE------ & $.898^{* *}$ & -.031 & .031 & .005 & -.060 & -.005 \\
- & & & & & & \\
Exp & & -.043 & .046 & -.046 & -.051 & -.016 \\
TJS & & & $.692^{* *}$ & $.550^{* *}$ & $.567^{* *}$ & $.727^{* *}$ \\
AC & & & & $.536^{* *}$ & $.608^{* *}$ & $.867^{* *}$ \\
CC & & & & & $.495^{* *}$ & $.814^{* *}$ \\
NC & & & & & & $.822^{* *}$ \\
OC & & & & & & - \\
\hline
\end{tabular}

Note: Exp=experience, TJS=teachers job satisfaction, AC=affective commitment, CC=continual commitment, $N C=$ normative commitment, $O C=$ organizational commitment

**. Correlation is significant at the .01 level (2-tailed).

The results in Table 4 showed that, there is a statistically significant positive relationship between teachers job satisfaction and over all organizational commitment $\left(\mathrm{r}=.727^{* *}, \mathrm{p}<.01\right)$. This means that as teachers job satisfaction increases, so does their organizational commitment. Similarly, there is statistically significant positive relationship between teachers' job satisfaction and the three subscales of organizational commitment (Table 4).

Table 4, also shows that statistically there is no significant relationship between age of the teachers and their job satisfaction $(r=-.031$, $\mathrm{p}>.05$ ) and between teaching experience of teachers and their level of job satisfaction ( $r=-.043, \mathrm{p}>.05)$. This entails that in the sampled schools, age and teaching experience of teachers are not significant determinants of teachers' job satisfaction.

\section{Demographic Variables and Teachers Job Satisfaction}

An independent t-test was employed to examine whether or not there is significant difference between male and female teachers in their level of job satisfaction. Table 5 shows the difference between male and female teachers in their level of job satisfaction.

Table 5: An independent t-test on Gender and Job Satisfaction $(n=118)$

\begin{tabular}{llllllll}
\hline Variable & Male & \multicolumn{7}{c}{ Female } \\
Gender & Mean & $S D$ & Mean & SD & $d f$ & $t$ & Sig \\
& 2.58 & 0.49 & 2.80 & .423 & 116 & 2.48 & 0.006 \\
\hline \multicolumn{7}{c}{ Significance levels. ${ }^{*} \mathrm{p}<.05,{ }^{* *} \mathrm{p}<.01,{ }^{* * *} \mathrm{p}<.001$}
\end{tabular}

Table 5 shows that there is statistically significant difference $t$ (116) $=2.48, \mathrm{p}(.006) \mathrm{p}<.05$ between male and female teachers in their level of job satisfaction. Female teachers have better job satisfaction than male teachers in the sampled schools. This entails that gender is a significant determinant of teacher's job satisfaction in the sampled schools. 
An independent t-test was employed to examine whether or not there is significant difference between teachers who got married and those who do not. Table 6 below shows the difference between married and unmarried teachers in their level of job satisfaction.

Table 6: An independent t-test on Marital Status and Teachers Job Satisfaction

\begin{tabular}{llllllll}
\hline Variable & Married & \multicolumn{7}{c}{ Unmarried } \\
\hline & Mean & $S D$ & Mean & SD & $d f$ & $t$ & Sig \\
Marital & 2.71 & .45 & 2.83 & .67 & 116 & .69 & 0.492 \\
status & & & & & & &
\end{tabular}

Significance levels. ${ }^{*} \mathrm{p}<.05,{ }^{* *} \mathrm{p}<.01,{ }^{* * *} \mathrm{p}<.001$

As shown in table 6, the average score on job satisfaction for married and single teachers were $(\mathrm{x}=2.71, \mathrm{SD}=.45)$ and $(\mathrm{x}=2.83, \mathrm{SD}=.67)$ respectively. The result shows that statistically there is no significance difference $\mathrm{t}(116)=.690$, $\mathrm{p}(.492) \mathrm{p}>.05$ between married and unmarried teachers in their level of job satisfaction. This implies that marital status was not significant determinant of teachers' job satisfaction in the sampled schools.

Level of teachers' education was another demographic variable that was examined in relation to job satisfaction. Table 7 below shows the an independent t-test result on the level of teachers education.

Table 7: An Independent t-test on Teachers level of education and their Job Satisfaction

\begin{tabular}{|c|c|c|c|c|c|c|c|}
\hline Variable & $\begin{array}{l}\text { Bachelor } \\
\text { Degree }\end{array}$ & & Diploma & & & & \\
\hline & Mean & $S D$ & Mean & $S D$ & $\overline{d f}$ & $t$ & Sig \\
\hline $\begin{array}{l}\text { Level of } \\
\text { Educ. }\end{array}$ & 2.66 & .52 & 2.73 & .46 & 116 & .573 & 0.568 \\
\hline
\end{tabular}

Significance levels. ${ }^{*} \mathrm{p}<.05,{ }^{* *} \mathrm{p}<.01,{ }^{* * *} \mathrm{p}<.001$

As it is indicated in table 7, the average score for teachers holding Bachelor degree and Diploma were $(\mathrm{X}=2.66, \mathrm{SD}=.52)$ and $(\mathrm{x}=2.73, \mathrm{SD}=.46)$ respectively. The difference between the two groups of teachers was statistically not significant $t(116)=.573$, $\mathrm{p}(.568) \mathrm{p}>.05$. This entails that level of education was not a significant determinant of teachers' level of job satisfaction in the sampled schools.

\section{Demographic variables and Organizational commitment of Teachers Gender}

An independent t-test was employed to examine whether or not there is significant difference between male and female teachers in their organizational commitment. Table 8 below shows the difference between male and female teachers in their organizational commitment. 
Table 8: An independent t-test on Gender and Organizational Commitment

\begin{tabular}{llllllll}
\hline Variable & Male & \multicolumn{7}{c}{ Female } \\
Gender & Mean & $S D$ & Mean & SD & $d f$ & $t$ & Sig \\
\hline \multicolumn{7}{c}{ Significance levels. ${ }^{*} \mathrm{p}<.05,{ }^{* *} \mathrm{p}<.01,{ }^{* * *} \mathrm{p}<.001$} &
\end{tabular}

As depicted in table 8, the average score of female and male teachers on organizational commitment scale were $(x=3.53, S D=.63)$ and $(x=3.30$, $\mathrm{SD}=.79$ ) respectively. The difference between the level of commitment of male and female teachers is statistically not significant $t(116)=1.726$, $p$ (.087) $\mathrm{p}>$.05. This indicates that there was no significant difference between male and female teachers on organizational commitment in the sampled primary schools.

\section{Marital Status}

Another demographic variable that was examined in relation to teachers' organizational commitment was their marital status. Table 9 shows the difference between married and single teachers in their level of organizational commitment.

Table 9: An independent t-test on Marital Status and Organizational Commitment

\begin{tabular}{llllllll}
\hline Variable & Married & \multicolumn{7}{c}{ Unmarried } \\
\hline Marital & Mean & $S D$ & Mean & SD & $d f$ & $t$ & Sig \\
status & 3.41 & .69 & 3.74 & .97 & 116 & .127 & 0.206 \\
\hline
\end{tabular}

Significance levels. ${ }^{*} \mathrm{p}<.05,{ }^{* *} \mathrm{p}<.01,{ }^{* * *} \mathrm{p}<.001$

Table 9, indicates that the difference between organizational commitment of single and married teacher was statistically not significant $t$ (116) $=1.27, \mathrm{p}(.206) \mathrm{p}>.05$. This indicates that marital status was not a significant determinant of teachers' organizational commitment in the sampled schools.

\section{Level of Educational}

An independent t-test was employed to test whether or not there is a difference between Bachelor Degree and Diploma holding teachers in their level of education. Table 10, below shows the difference between the two groups of teachers in terms of their level of commitment.

Table 10: An independent t-test on Educational Level and Organizational Commitment

\begin{tabular}{|c|c|c|c|c|c|c|c|}
\hline Variable & $\begin{array}{l}\text { Bachelor } \\
\text { Degree }\end{array}$ & & Diploma & & & & \\
\hline & Mean & $S D$ & Mean & $S D$ & $d f$ & $t$ & Sig \\
\hline $\begin{array}{l}\text { Level of } \\
\text { Educ. }\end{array}$ & 3.20 & .77 & 3.45 & .70 & 116 & 1.37 & 0.174 \\
\hline
\end{tabular}

Significance levels. ${ }^{*} \mathrm{p}<.05,{ }^{* *} \mathrm{p}<.01,{ }^{* * *} \mathrm{p}<.001$ 
Table 10 above depicted that the difference between the average score of bachelor degree and diploma holders in their level of organizational commitment was not statistically significant t (116) $=1.37, \mathrm{p}(.160) \mathrm{p}>.05$. This indicates that level of education does not significantly determine teachers' level of organizational commitment in the sampled schools.

\section{Discussion}

One of the objectives of this study was to conduct an empirical investigation about teachers' level of job satisfaction and organizational commitment among primary schools of Ethiopia. The analysis of levels of satisfaction and organizational commitment found that an overwhelming majority of teachers sampled had positive organizational commitment eventhough their level of job satisfaction is below average . Several past studies also positively assessed teachers' level of job satisfaction in different contexts (see for for example; Wu \& Wu, 2001; Fon, 2007;Demirtaş, 2010; Raza and Nawaz, 2011). In contrast Raj and Marry (2004) attempted a study job satisfaction of teachers in on Pondicherry region and found that job level of satisfaction was low. Abbasi (2003), also conducted a comparative study of job satisfaction among primary school teachers in Iran and India. It was revealed that in both countries, more than $50 \%$ of teaches have medium level of job satisfaction, which shows that both countries have serious problems about situation of teachers in their societies and educational system.

As noted by Luthans (1995), high job satisfaction levels are associated with characteristics such as less individuals' complains and convenience to learn their new duties. Teachers' satisfaction levels directly reflect on classroom activities and consequently reflect on students. The schools, where teachers' job satisfaction levels are low, are expected to be less successful (Karsl1, 2006: 205). According to Latham (1998, 83), “job satisfaction can do far more than help retain teachers; it can improve their teaching." This implies that satisfied teachers can contribute significantly to the improvement student's academic performance and school effectiveness at large. On the issue Woods and Weasmer (2002) suggested that when teachers are satisfied, the rate of attrition is reduced, collegiality is enhanced, and job performance improves. Werner (2007), also asserted that only satisfied employees seem more likely to display positive behavior that contributes to the overall functioning of the organization. In this regard, management in organizations must be more concerned with the extent to which their employees experience job satisfaction and are involved in their jobs.

Similarly Organizational commitment levels of the participants were found to be slightly above average. Similar findings have been consistently reported by several past studies (see for example; Price \& Mueller, 1981; 
Williams \& Hazer, 1986; Mathieu \& Zajac, 1990; Lok \& Crawford, 2001; Kahveci, 2010; 2011; Raza and Nawaz, 2011).

The finding of this study also showed that there is a positive relationship between teachers' job satisfaction and organizational commitment. This finding is in line with the findings of some of the past studies that have found positive relationship between job satisfaction and organizational commitment of teachers (see Shann, 1998; Wu \& Norman, 2006; Sweeney \& Quirin; 2009).

The study further investigated the relationship between gender, age, teaching experience, marital status, level of education and teachers' level of job satisfaction. The result showed the difference between female and male teachers in their level of job satisfaction is statistically significant. Female teachers are more satisfied with their job with compared to their male counterparts. This finding is in conformity with the findings of several past studies (Abbasi, 2003; Kim, 2005; Bindu , 2007 ). This result however, contradicts some studies that have suggested that men and women exhibit similar levels of satisfaction (Brush, Moch and Pooyan, 1987, Clark, Oswald\& Warr, 1996)

According to the finding of this study, there is no significant difference between teachers having different level of education in their job satisfaction. This finding is not in consistent with the finding of some of the past studies which found a negative relationship between educational level and job satisfaction (Hickson \& Oshagbemi; 1999; Akiri \& Ogborugbo, 2009).

The absence of significant difference between Bachelor Degree and diploma holding teachers in their level of satisfaction is in conformity with the finding of some earlier studies that found no significant relationship between the teachers' education and job satisfaction (Agarwal, 1991; Tillman \& Tillman, 2008).

This study showed that teachers' perceived a high level of organizational commitment in their respective schools. Furthermore, it was clear that length of teaching service has no significant influence on teachers' organizational commitment. This finding contradicts with some earlier studies that asserted employees with longer organizational tenure (i.e., the length of employment with the organization) tend to be more committed than individuals or those with a shorter organizational tenure (Price \& Mueller, 1981; Luthans, MC Caul, Dodd, 1985; Mathieu \& Zajac, 1990Grau et al., 1991; Kacmar, Carlson, \& Brymer, 1999; Kiyak et al., 1997; Lok \& Crawford, 2001).

This study also showed that there is significant difference between male and female teachers in their level of organizational commitment. The finding contradicts with recent studies that found no relationship between 
gender and organizational commitment (Kacmar, Carlson, \& Brymer, 1999; Van der Velde, Bossink, \& Jansen, 2003). However, there are studies from the past that showed women have lower level of organizational commitment compared to their male counter parts(Dixon wt al., 2005) and the vice versa (Kargar et al, 2012).

According to the findings of this study, the teachers' levels of education have no significant influence on their perceived organizational commitment. This was not compatible with the findings of some earlier studies that asserted more educated employees showing lower levels of commitment, most likely because they have higher expectations or greater alternative job opportunities (Glisson \& Dunick, 1988; Mathieu \& Zajac; 1990; Grau et al., 1991; , Eskildsen, Kristensen \& Westland, 2004;). Yet, it was found similar with other studies that showed the existence of positive relationship between level of education and organizational commitment (Akintayo et al., 2010; Salami, 2010,).

Although the finding of this study showed that marital status is not significant determinant of teachers' commitment, some earlier studies indicated that married individuals report higher levels of commitment than unmarried individuals, because of their greater financial burdens and family responsibilities (Mathieu \& Zajac, 1990; Kacmar et al., 1999;Tsui et al., 1994,). In contrast, there are also studies that showed unmarried teachers are more committed (Ishtag et al., 2010; Saifuddin \& Nawaz, 2012).

Age of teachers according to this study does not significantly determine the level of satisfaction. This finding is inconsistent with the study of Colbert and Kwon who found no relationship between age and commitment of teachers (Colbert and Kwon, 2000). Nevertheless, the finding is not consistent with some earlier studie that indicated older employees are more committed than the younger ones (Akintayo et al., 2010).

\section{Conclusion and Implications}

One of the most important findings of this study is that there is a positive relationship between teachers' job satisfaction and organizational commitment. This implies that the schools and district education offices can enhance the level of teachers' commitment to their schools by creating a more conducive and more satisfying environment in the work place. Apparently, in Ethiopian context, schools are not authorized to decide on pay and other monetary incentives. Yet, they can enhance teachers' job satisfaction by creating better training and development opportunities, improving leadership and management support, promoting accountability and involving teachers in decision-making made at school level.

Another important finding of this study is the observed positive relationships between scores of demographic variables, job satisfaction and 
organizational commitment. Some of these findings contradict with the existing literature on these fields, others are in consistent with. For example, why are demographic variables such as age, marital status, level of education and service year have no relationship with teachers' job satisfaction and organizational commitment while they have proved to have some relationship in several earlier studies? This implies that more studies need to be undertaken to have better understanding of the nature of the relationship between teachers demographic variables, job satisfaction and organizational commitment in developing countries context .

\section{References:}

Aamodt, M.G. (2007). Industrial/Organisational Psychology: An Applied Approach. Belmont, CA: Wadsworth Cengage Learning.

Abbasi, P. (2003) A comparative study of job satisfaction among primary school teachers in India. New Frontiers in Education, Vol. XXXIII (02) [2].

Agarwal, J. (1991). A study of job Satisfaction of Primary and Secondary School Teachers, Fourth Survey of Education Research Vol. - I New Delhi: NCERT. [3].

Akintayo, D. I. Work-Family Role Conflict and Organizational Commitment Among Industrial Workers In Nigeria. JPC. 2(1): 1-8, (2010).

Akiri, AA. \& Ogborugbo,NM. (2009). Analytic Examination of Teachers' Career Satisfaction In Public Secondary Schools. Studies on Home and Community Science, 3(1):51-55.

Aklilu Habte. (1967). Brain Drain In The Elementary School: Why Teachers Leave The Profession. The Ethiopian Journal of Education, 1(1), 27-39

Ayalew Shibeshi, A. (1991). Problems teachers face and conditions that create discontent in them. Addis Abeba; Research report sponsored by Ethiopian Teacher Association.

Ayeni,C.O.\& Phopoola,S.O.(2007). 'Work Motivation, Job Satisfaction, and Organizational Commitment of Library Personnel in Academic and Research Libraries in Oyo State, Nigeria', Library Philosophy and Practice 2007 Bangalore city. Experiments in education, 28 (9), 159-163.

Bindu, C.M, (2007). Relationship between job satisfaction and stress coping skills of primary school teachers, EDUTRACKS, Vol. 06(05). [6].

Brown, D. and Sargeant, M.A. (2007). Job satisfaction, organizational commitment, and religious commitment of full-time university employees. Journal of Research on Christian Education, 16, 211-241.

Brush, D.H., Moch, M.K. and Pooyan, A. (1987) Individual Demographic Differences and Job Satisfaction', Journal of Occupational Behaviour, 8(1): 139-55.

Day, C. (2000). "Stories of change and professional development: The costs of commitment. In C. Day, A. Fernandez, T. Hauge, \& J. Moller (Eds.)”. 
The Life and Work of Teachers: International Perspectives in Changing Times (pp. 109- 129). London: Falmer Press,

Chaplain, R. P. (1995). Stress and job satisfaction: A study of English primary school teachers. Educational Psychology, 15, 473-489. Chicago.

Clark, A., Oswald, A. and Warr, P. (1996) _Is Job Satisfaction U-shaped in Age? ', Journal of Occupational and Organizational Psychology, 69: 57-81. Clugston, M. (2000). The mediating effects of multidimensional commitment on job satisfaction and intent to leave. Journal of Organizational Behavior, 21(4), 477-486.

Colbert, A.E.,\& Kwon, L.G.(2000). Factors related the organizational commitment of college and university auditors. Journal of Managerial Issues, Vol. 12, No. 4, 484-501.

Crossman,A.andHarris,P.(2006).Job satisfaction of secondary school teachers. Educational Management and Leadership, Vol. 34 No. 1, 29-46.

Daneshfard,C.\& Ekvaniyan, E.K. (2012).Organizational commitment and job satisfaction in Islamic Azad University,Inter disciplinary Journal of Contemporary

Research in

Business,3(9);Availableat:https://docs.google.com/viewer?a=v\&q=cache:kQ RWPM0grUwJ:www.journalarchieves14.webs.com/168 181.pdf. Retrieved August 4, 2012

Delaney, B. (2002). Alternative work arrangements: Do they make economic sense?

RetrievedAugust5,2011,from,http://www.hrpa.ca/HRThoughtLeadership/Do cuments/hrproarchive/2002/oct-nov2002.pdf

Demirtaş, Z. (2010).Teachers' job satisfaction levels. Procedia Social and Behavioral Sciences, 9, 1069-1073

Dinham, S. And Scott. (1998). A Three Domain Model of Teacher and School Executive Career Satisfaction. Journal of Educational Administration, 36, 362-378.

Dixon, M. A., Furner, B. A., Cunningham, G. B., Sagas, M., Kent, A. (2005): Challenge is key: An investigation of affective organizational commitment in undergraduate interns. Journal of Education for Business,( 80), 172-180

Dixon, M.A., Cunningham, G.B., Sagas, M., Turner, B.A. and Kent, A. (2005), "Challenge is key: an investigation of affective organizational commitment in undergraduate interns", Journal of Education for Business, (7)172-80.

Eskildsen, J. K., Kristensen, K. and Westlund, A. H., (2004) "Work Motivation and Job Satisfaction in the Nordic countries", Employee Relations, ( 26)122 - 136. 
Fenot, B. A. (2005). Teacher job satisfaction and dissatisfaction: An empirical study of urban teachers in Ethiopia. (Doctoral thesis). Teacher College, Columbia University.

Fon, T P. (2007). Job satisfaction among academic staff in the University of Buea. The Exceptional Child, 9 (2), 338-344. Microsoft Encounter Dictionary (2009). Satisfaction www.freedownloadscenter.com/terms/ microsoft-encounter

Gedefaw, K. M. (2012). Job satisfaction of secondary school teachers in Ethiopia.(Unpublished doctoral dissertation). University of South Africa, South Africa.

Getachew, Haile. (1999). Stress in School Teachers. the Ethiopian Journal of Education, 19(2), 15-51.

Glisson ,C. and Durick, M. (1988). Predictors of job satisfaction and organizational commitment in human service organizations. Administrative Science Quarterly, 33(1), 61-81

Grau, L. Chandler, B. Burton, B. , \& Kolditz, D., (1991). Institutional loyalty and job satisfaction among nurse aides in nursing homes. Journal of Aging and Health, 3, 47-65.

Hickson, C. and Oshagbemi, T. (1999), "The effect of age on the satisfaction of academics with teaching and research”, International Journal of Social Economics, Vol. 26 No. 4, pp. 537-44.

Ishfaq Ahmed (2010). Effects of Motivational Factors on Employees Job Satisfaction: Hailey College of Commerce, University of the Punjab, Pakistan. International Journal of Business And Management, Vol 5, No. 3

Kacmar, K. M., Carlson, D. S. \& Brymer, R. A. (1999). Antecedents and consequences of organizational commitment: A comparison of two scales. Educational and Psychological Measurement, 59(6), 976-994.

Kahveci, G.( 2010). Relationships between organizational commitment and organizational silence in elementary schools (Unpublished Master Thesis), Firat University, Elazig

Karavas, E. (2010) How Satisfied Are Greek EFL Teachers with Their Work? Investigating the Motivation and Job Satisfaction Levels of Greek EFL Teachers. Porta Linguarum, 14, 59-78.

Kargar, M. (2012). Evaluation of Organizational Commitment of Employees in University; Case Study: Islamic Azad University. J. Basic. Appled Science Research, (5) 5017-5021.

Karsl1, M.D. (2006). Effective school leadership. Istanbul: Morpa.

Kim, S. (2005). Gender differences in job satisfaction of public employees: a study of Seoul Metropolitan government, Korea. Sex Roles, 52(9/10):667681. 
Kiyak, H. A., Namazi, K. H., \& Kahana, E. F., (1997). Job commitment and turnover among women working in facilities serving older persons. Research on Aging (19)223-246.

Lawrence, A.,and Lawrence, P. (2009). Values congruence and organizational commitment: $\mathrm{P}-\mathrm{O}$ fit in higher education institutions. Journal of Academic Ethics, 7(4), 297-314.

Lok, P., \& Crawford, J., (2001). Antecedents of organizational commitment and the mediating role of job satisfaction. Journal of Managerial Psychology, 16, 594-613.

Luthans, F. (1992), Organizational Behavior, Sixth Edition, and New York: Mc Graw Hill, Inc Managerial Psychology, 15(5):407-426.

Luthans, F., McCaul, H. S., Dodd, N. G. (1985): Organizational commitment: A comparison of American, Japanese and Korean employees. The Academy of Management Journal, 28 (1), 213-219. 28.

Manna Olango and Tesfaye Semela. (2001). Determinants of teachers' decision to leave or stay in the teaching profession. The Ethiopian Journal of Education, XX (1), 1-23.

Mathieu, J. \& Zajac, D.(1990). 'A review and meta-analysis of the antecedents, correlates and consequences of organizational commitment', Psychological Bulletin, 108(2): 171-194.Mc Graw-Hill Book Company

Mathieu, J. E. \& Zajac, D. M. (1990). A review and meta - analysis of the antecedents, correlates, and consequences of organizational commitment. Psychological Bulletin, 108 (2), 171 - 194.

Meyer J P and Herscovitch L (2001), "Commitment in the Workplace: Toward a General Model”, Human Resource Management Review, Vol. 11, pp. 299-326.

Meyer, J.P. \& Allen, J.N. (1997).Commitment in the Workplace Theory, Research and Application .Sage Publications, Thousand Oaks, CA.

Meyer, John P., Stanley, David J., Herscovitch, Lynne, Topolnytsky, Laryssa. (2002). Affective, Continuance, And Normative Commitment to the Organization: A Meta-Analysis of Antecedents, Correlates, and Consequences. Journal of Vocational Behavior, 61, 20-

Morrison, R. (2008). 'Negative relationships in the workplace: Associations with organisational commitment, cohesion, job satisfaction and intention turnover', Journal of Management and Organization, 14: 330-344.

Mowday, R. T. Porter, L. W., \& Steers, R. M. (1982). Employee organization linkages: The psychology of commitment, absenteeism, and turnover. Academic Press: San Diego.

Ololube, N.P. (2006). Teachers Job Satisfaction and Motivation for School Effectiveness: An Assessment. ERIC Number: ED496539, 19 p. 
Park, S.Henkin, A. B., \& Egley, R. (2005). Teacher team commitment, teamwork, and trust: exploring associations. Journal of Educational Administration, 43(5), 462-479. Pitman Publishing

Pohlman, R.A. \& Gardiner, G.S. (2000). Value Driven Management: How to Create and Maximize Value Over Time for Organizational Success, AMACOM, New York, NY.

Price, J., \& Mueller, C., (1981). A causal model of turnover for nurses. Academy of Management Journal, 34, 543-565.

Raj, S. and Mary, (2005). Job satisfaction of teachers in Purucherry region.Indian education abstracts.Vol-6.

Raza,M.A. and Nawaz, M.M. (2011). Impact of job enrichment on employees' job satisfaction, motivation and organizational commitment: evidence from public sector of Pakistan. European Journal of Social Sciences, 23(2), 220-226.

Robbins, SP. \& Coulter, M. (2005). Management. Pearson Education. Inc; and Dorling Kindersley Publishing Inc, India.

Saifuddin, Nawaz, A. Jan, F. (2012)Predicting Job-Satisfaction among the Academicians of Universities in Kpk, Pakistan. IEL. 2(2): 34-45.

Salami,S.O. (2008), Demographic and Psychological Factors Predicting Organizational Commitment Among Industrial Workers. Anthropologist, 10, 31-38.

Shan, M.H. (1998). Professional commitment and satisfaction among teachers in Urban middle schools. Journal of Educational Research, 92, 6773.

Shann, M. H. (2001). Professional Commitment and Satisfaction among Teachers in Urban Middle schools. The Journal of Educational Research, 92 No. 2, 67- 73.

Spector, P. E. (1997). Job satisfaction: Application, assessment, causes and consequences. London: SAGE

Srisrankulwong, S.(2005). Factors Affecting Teacher Commitment in Thai Private Schools. The University of Nottingham, Nottingham

Sweeney, J.T. \& Quirin, J.J. (2009). Accountants as layoff survivors: A research note. Accounting, organizations and society, 34, 787- 795.

Taşdan,M. and Tiryaki, E. (2008). Comparison of the level of job satisfaction between at private and state primary school teachers. Education and Science, 33(147), 54-70.

Tillman, WR. \& Tillman, CJ. (2008). And you thought it was the apple: a study of job satisfaction among teachers. Academy of Educational Leadership Journal, 12(3):1-19.

Tsui, K., Leung, T., Cheung, Y., Mok, H., \& Ho, W., (1994): The relationship of teacher's organizational commitment to their perceived 
organizational health and personal characteristics in primary schools. CUHK Journal of Primary Education, 4 (2), pp. 27-41

Tsui,K.T. \& Cheng, Y.C. (1999). School organizational health and teacher commitment: a contingency study with multi-level analysis. Educational Research and Evaluation, 5(3), 249-68.

Van der Velde, M. E., Bossink, C. J., \& Jansen, P. G., (2003). Gender differences in the influence of professional tenure on work attitudes. Sex Roles, 49, (3/4), 153-162.

Werner, A. (2007).Organizational Behavior: A Contemporary South African Perspective. Pretoria: Van Schaik Publishers.

Williams, L. J. and Hazer, J. T. (1986), Incidents and Consequences of Satisfaction and Commitment in Turnover Models: A Reanalysis Using Latest Variables Structural Equation Methods, Journalf Applied Psychology, 71, 219-231

Wisniewski, L. \& Gargiulo, R. (1997). Occupational Stress and Burnout among Special Educators: A review of the literature. The Journal of Special Education, 31, 325-346.

Woods, A. M. \& Weasmer (2002). Maintaining job satisfaction: Engaging professionals as active participants. The Clearing House. 75, No. 4, $186-$ 189.

Wu \& Norman. (2006). A Study of the Relationship between Manager's Leadership Style and Organizational Commitment in Taiwan's International Tourist Hotels. Asian Journal of Management and Humanity Sciences 1(3), 434-452.

WU Huei-Jane \& You-I WU. (2001). A study on Elementary School Teachers Job Satisfaction and its relationship with their social network, Job Characteristics. Bulletin of Educational Research, 46, 147-180.

Yücel, I. (2012). Examining the Relationships among Job Satisfaction, Organizational Commitment and Turnover Intention: An Empirical Study. International Journal of Business and Management, 7(20). Retrieved from: http://dx.doi.org/10.5539/ijbm.v7n20p44 